\title{
GLOBAL JUSTICE AND PRACTICE-DEPENDENCE: CONVENTIONALISM, INSTITUTIONALISM, FUNCTIONALISM*
}

\author{
Laura Valentini \\ The Queen's College, Oxford \\ Published in The Journal of Political Philosophy
}

\section{INTRODUCTION}

Central to contemporary political theory is the question of whether domestic principles of distributive justice should extend to the world at large. The literature is divided on this question: cosmopolitans answer it in the positive, social liberals in the negative. ${ }^{1}$

The disagreement between these two sets of views is most commonly traced to differences in their substantive moral commitments. It is said that while cosmopolitans take individual human beings as the ultimate sources of moral concern, social liberals surreptitiously attribute moral primacy to political communities. Due to their seemingly communitarian inclinations, social liberals have often been accused of discriminating in favour of compatriots, thereby betraying the fundamental liberal commitment to persons' moral equality qua rational and purposive agents. A true liberal, so the argument goes, cannot allow for something as morally arbitrary as national belonging to determine the scope of principles of distributive justice.

\footnotetext{
* I am grateful to Simon Caney, Elizabeth Cripps, Bob Goodin, Robert Jubb, Tamara Jugov, David Karp, Saladin Meckled-Garcia, Cécile Laborde, Thom Porter, Miriam Ronzoni, Federico Zuolo and the anonymous reviewers of this paper for their comments on earlier versions of it. I also wish to thank the audience at 'Brave New World' (University of Manchester, June 2007) and at the Royal Institute of Philosophy Seminar Series (Roehampton University, November 2008) for helpful discussion. Finally, my biggest thanks go to Christian Barry, for his invaluable written comments on an earlier draft, and to Christian List for his continued encouragement.

${ }^{1}$ For cosmopolitanism see, e.g., Charles R. Beitz, Political Theory and International Relations with a new afterword (Princeton, NJ: Princeton University Press, 1999) and Thomas W. Pogge, Realizing Rawls (Ithaca: Cornell University Press, 1989). For social liberalism see, e.g., John Rawls, The Law of Peoples (Cambridge, MA: Harvard University Press, 1999); Thomas Nagel, 'The Problem of Global Justice', Philosopby and Public Affairs, 33 (2) (2005), 113-47, and David Miller, On Nationality (Oxford: Clarendon Press, 1995) and National Responsibility and Global Justice (Oxford: Oxford University Press, 2007).
} 
In recent years, advocates of (different versions of) social liberalism have developed a novel and clever response to this long-standing cosmopolitan charge, emphasising that the rationale behind their outlook is not substantive (i.e., a lack of commitment to the moral primacy of persons) but methodological (i.e., a particular commitment to how moral principles should be justified). On their view, moral principles are 'practice-dependent' ${ }^{2}$. That is, they are constructed by interpreting the point of the specific practice they aim to regulate. Since the point of global practices differs from that of domestic ones, social liberals assert that it is possible to deny the applicability of principles of distributive justice to the world at large without thereby violating the liberal commitment to the moral equality of persons. ${ }^{3}$

My aim in this paper is twofold: I want to (i) explore the practice-dependent approach and (ii) ask whether it provides a successful defence of social liberalism. Unfortunately, I argue, it does not. My argument proceeds as follows. In section II, I briefly outline the main features of social liberalism and explain why its liberal credentials have appeared dubious in the eyes of cosmopolitan critics. In section III, I set out the methodological case for social liberalism by focusing on the 'practice-dependent approach' and highlighting its most attractive features. In sections IV, V, and VI, I distinguish, following Andrea Sangiovanni, between two versions of this approach, 'cultural conventionalism' and 'institutionalism', and argue that both betray the liberal commitment to the moral equality of persons. ${ }^{4}$ On the one hand, cultural conventionalism has no resources to ensure that the content of principles of distributive justice is compatible with the moral equality of persons.

\footnotetext{
2 Andrea Sangiovanni, 'Justice and the Priority of Politics to Morality', Journal of Political Philosophy, 16 (2) (2008), 137-64.

3 Aaron James, 'Constructing Justice for Existing Practice: Rawls and the Status Quo', Philosophy and Public Affairs, 33 (3) (2005), 281-316; Andrea Sangiovanni, 'Global Justice, Reciprocity, and the State', Philosophy and Public Affairs, 35 (1) (2007), 3-39; Samuel Freeman, 'The Law of Peoples, Social Cooperation, Human Rights, and Distributive Justice', Social Philosophy and Policy, 23 (1) (2006), 29-68, and Saladin Meckled-Garcia, 'On the Very Idea of Cosmopolitan Justice: Constructivism and International Agency', Journal of Political Philosophy, 16 (3) (2008), 245-71.

${ }^{4}$ Sangiovanni, 'Justice and the Priority of Politics to Morality'.
} 
On the other hand, institutionalism has no resources to ensure that the scope of principles of distributive justice remains true to this fundamental commitment. Finally, in section VII, I consider a third version of the practice-dependent approach, which I call 'functionalism', and show that it does not suffer from the drawbacks of its conventionalist and institutionalist counterparts. This version of practice-dependence, however, more easily lends itself to cosmopolitan than social liberal conclusions.

\section{SOCIAL LIBERALISM AND THE COSMOPOLITAN CHARgE OF ARBITRARINESS}

Social liberals hold that the principles of distributive justice they typically defend in the domestic context are only relevant to the assessment of agents' mutual relations qua members of political communities, and do not extend to the world at large. Variants of this view have been advocated by prominent political philosophers, most famously John Rawls. ${ }^{5}$ Since the advocates of social liberalism I will discuss in this paper take the lead from Rawls's view, so will I. In what follows, I will consider Rawls's position on global justice as an archetypical example of social liberalism.

Although Rawls is a fervent advocate of domestic distributive justice, his outlook on international morality has no room for such distributive principles. Internationally, he defends the sovereign equality, territorial integrity and self-determination of nation-states, and affirms a duty of (humanitarian) assistance between them, ensuring that each community possesses the minimum level of resources required to sustain its social and political life. For Rawls, international morality is a matter of mutual respect and assistance between different political communities. On his picture, distributive justice does not apply beyond state borders. ${ }^{6}$ There is an important difference between an international morality based on justice and one based on assistance. ${ }^{7}$

\footnotetext{
${ }^{5}$ Nagel, 'The Problem of Global Justice'; Rawls, The Law of Peoples, and Miller, On Nationality.

${ }^{6}$ Interestingly, in The Law of Peoples, p. 42 n. 52, Rawls assumes that fair background conditions obtain in the international realm. In so saying, Rawls paradoxically designs his theory of international justice already
} 
First, principles of distributive justice are particularly stringent: they determine what persons' rights are, what they are entitled to. In doing so, these principles draw the boundaries within which each person can pursue her ends and goals without violating others' rights to do the same. For example, by stealing your property, I breach a duty of justice: you have a right to use that property to pursue your own ends and goals, and I deprive you of it.

Second, given the liberal commitment to the moral equality of persons, from a liberal perspective principles of distributive justice are typically egalitarian in form. That is, they demand an equal, or roughly equal, distribution of entitlements across persons. ${ }^{8}$ When contemporary liberal philosophers (including social liberals) talk about distributive justice, it is to this kind of egalitarian justice that they refer to.

Duties of assistance, on the other hand, are requirements to help those in need (at reasonable costs) with resources one rightfully possesses on grounds of justice. 'This suggests that duties of justice are prior to, and weightier than, duties of assistance. In particular, holding the content of the duties constant, duties of justice are more stringent than

presupposing that international distributive justice has been realised. On this see Thomas W. Pogge, 'The Incoherence between Rawls's Theories of Justice', Fordham Law Review, 72 (5) (2004), 1739-59, p. 1751.

${ }^{7}$ I offer a more detailed account of the distinction between justice and assistance in 'Justice and Assistance: Three Approaches and a Fourth One' (unpublished manuscript).

${ }^{8}$ See, e.g., John Rawls, A Theory of Justice (Oxford: Oxford University Press, 1999 rev. ed.), and Ronald Dworkin, Sovereign Virtue (Cambridge, MA: Harvard University Press, 2000).

${ }^{9}$ Notice that assistance grounds genuine duties, and it is not just a matter of supererogation. See Allen Buchanan, 'Justice and Charity', Ethics, 97 (3) (1987), 558-75, p. 559 n. 1. 
duties of assistance. ${ }^{10}$ For instance, I have a more stringent duty to feed the starving if the food I happen to possess rightfully belongs to them rather than to me. ${ }^{11}$

In addition to being ceteris paribus less stringent than duties of justice, duties of assistance are sufficientarian, rather than egalitarian in form. In other words, instead of placing limits on inequalities across persons, they aim to relieve absolute deprivation, by ensuring that everyone's needs are satisfied. ${ }^{12}$ Inequalities beyond this threshold of needs satisfaction are considered morally irrelevant from the viewpoint of assistance.

In short, social liberals like Rawls defend stringent duties of egalitarian justice at home, and weaker duties of sufficientarian assistance abroad. ${ }^{13}$ As I noted in the introduction, cosmopolitans typically object to this moral picture, arguing that it arbitrarily discriminates in favour of compatriots. This charge is premised on a commitment to what might be

${ }^{10}$ I owe this qualification to Thomas Pogge, 'Severe Poverty as a Violation of Negative Duties', Ethics and International Affairs, 19 (1) (2005), 55-83, p. 76. This qualification is very important. As a reviewer has pointed out to me, it would indeed be implausible to claim that justice always takes priority over assistance. For instance, it seems absurd to say that the duty to return someone's pencil is more stringent than the duty to help the starving.

${ }^{11}$ See Brian Barry, 'Humanity and Justice in Global Perspective', in Brian Barry, Liberty and Justice: Essays in Political Theory 2 (Oxford: Clarendon Press, 1991), 182-210, p. 209. See also Sylvie Loriaux, 'Beneficence and Distributive Justice in a Globalising World', Global Society, 20 (3) (2006), 251-65.

12 On the distinction between absolute and relative deprivation in the context of the debate on global justice see Michael Blake, 'Distributive Justice, State Coercion, and Autonomy', Philosophy and Public Affairs, 30 (3) (2001), 257-96.

${ }^{13}$ Someone might suggest that while social liberals do indeed deny global egalitarianism, they do not consider sufficientarian duties to help the needy a matter of assistance, but a stringent matter of justice. This is the view defended by Sangiovanni in 'Global Justice, Reciprocity, and the State', but it is unclear whether theorists like Rawls, Miller (in On Nationality), Nagel, and Meckled-Garcia also endorse it. Since they label their international duties 'duties of assistance' and 'humanitarian duties' it would seem not. (Note that Miller's more recent views on this matter are particularly complex. For discussion see Laura Valentini, 'Social Liberal or Cosmopolitan?', Global Justice: Theory Practice Rhetoric, 2 (2009), 50-3.) Moreover, social liberals typically prioritise the needs of fellow-citizens over those of distant strangers. This means that, holding the content of the duties constant, social liberals regard duties to help compatriots as more stringent than duties to help foreigners. Finally, even if we assumed that, for social liberals, domestic and international distributive duties have the same (justice-based) stringency, the former would still be egalitarian and the latter sufficientarian. This disanalogy alone is sufficient to trigger cosmopolitan concerns about arbitrary discrimination between compatriots and foreigners. 
regarded as the greatest common denominator of all liberal outlooks on justice: the principle of respect for persons as moral equals. Since one of the pillars of liberal justice is the idea that every human being should be treated with equal respect, restricting the scope of principles of distributive justice to the domestic arena, so the cosmopolitan argument goes, is inconsistent with calling oneself a liberal. Equal respect requires the inclusion of each human being within the scope of justification, and by confining distributive justice to the domestic arena, cosmopolitans protest, social liberals are guilty of arbitrary exclusion.

This general cosmopolitan charge can be further articulated in various ways, depending on how the principle of equal respect is thought to ground obligations of global distributive justice. Some cosmopolitans, for instance, believe that there exist global institutional practices - typically, a Rawlsian 'global basic structure' - which warrant the application of the same conception of justice as liberals endorse at the domestic level. ${ }^{14}$ Others believe that such a global extension of principles of domestic justice is practice-independent: that is, it follows from the principle of equal respect directly and independently of the existence of appropriate global practices. ${ }^{15}$ Others still put forward the weaker contention that the concept of justice - with its special stringency and focus on agents' relative shares - applies to the global order, but do not go so far as to claim that the specific conception of justice that liberals defend in the domestic arena is global in scope. ${ }^{16}$

For the purposes of this paper, I need not endorse any one of these forms of cosmopolitanism. Instead, I only consider the cosmopolitan charge of betrayal of liberal

\footnotetext{
${ }^{14}$ Pogge, Realizing Rawls.

${ }^{15}$ Simon Caney, Justice beyond Borders: A Global Political Theory (Oxford: Oxford University Press, 2005); KokChor Tan, Justice without Borders: Cosmopolitanism, Nationalism and Patriotism (Cambridge: Cambridge University Press, 2004), and Charles R. Beitz, 'Cosmopolitan Ideals and National Sentiment', The Journal of Philosophy, 80 (10) (1983), 591-600.

${ }^{16}$ Cf. Joshua Cohen and Charles Sabel, 'Extra Rempublicam Nulla Justitia', Philosophy and Public Affairs, 34 (2) (2006), 147-75, and A.J. Julius, 'Nagel's Atlas', Philosophy and Public Affairs, 34 (2) (2006), 176-92. See also Charles Beitz's distinction between 'weak' and 'strong' cosmopolitanism in Political Theory and International Relations, pp. 198-99. For the distinction between concept and conception see Rawls, A Theory of Justice, p. 5.
} 
normative individualism in its most general formulation, and examine how social liberals have recently tried to respond to it by drawing attention to their distinctive methodology. The social liberal account of international morality, they argue, does not result from a dubious shift from the primacy of individuals to the primacy of political communities. Instead, it is the product of a distinctive approach to the design and justification of normative principles - an approach which is fully in line with liberal normative individualism.

\section{THE PRACTICE-DEPENDENT APPROACH}

According to this approach, 'the content, scope, and justification' of moral principles depend on the point of the practice they are meant to regulate. ${ }^{17}$ That is, moral principles are constructed by interpreting the point of different social practices. Social practices are here understood to encompass both formal institutional structures, and informal social rules. Although this practice-dependent approach has recently been revived within debates on global justice, as participants in these debates recognise, its classic and most articulate statement may be found in Ronald Dworkin's account of 'constructive interpretation'.

Dworkin's account begins with the observation that members of fairly developed communities often take a critical attitude towards the practices in which they participate. ${ }^{18}$ They all regard them as having a point, as expressing a value, but disagree about the value in question or, less radically, about the actions that would best convey it. When this is the case, in order fully to understand the meaning of their practices, participants have to

\footnotetext{
${ }^{17}$ Sangiovanni, 'Justice and the Priority of Politics to Morality', p. 138.

18 Ronald Dworkin, Law's Empire (Oxford: Hart Publishing, 1986), ch. 2. For an overview of Dworkin's theory of interpretation see Stephen Guest, Ronald Dworkin (Edinburgh: Edinburgh University Press, 1997, $2^{\text {nd }}$ ed), ch. 2 .
} 
engage in an exercise of 'constructive interpretation'. ${ }^{19}$ The process of constructive interpretation is modelled in terms of three analytically distinguishable phases. ${ }^{20}$

The first, 'preinterpretive' phase is devoted to the identification of 'the raw data of interpretation', namely the social practice to be interpreted. ${ }^{21}$ For interpretation to be viable, a considerable degree of consensus within the interpretive community is necessary at this stage. In the second, 'interpretive' phase, each interpreter interrogates herself about the meaning of the practice under analysis. That is, she seeks to justify the practice in light of what she takes to be its point and purpose, i.e., the values it is meant to foster. For her activity to count as an exercise in interpretation as opposed to mere invention, the interpreter must also meet certain criteria of fit with the 'raw data' identified during the preceding phase, criteria on which interpreters need roughly to agree for their disputes to be meaningful. ${ }^{22}$ Finally, during the 'postinterpretive or reforming stage', interpreters revise their understandings of what the practice 'really requires' so as to best express its point and purpose. $^{23}$

To see how this interpretive process is supposed to work, consider the practice of dining in an Oxbridge College, and imagine its participants taking an interpretive attitude towards it. ${ }^{24}$ At the first, preinterpretive stage, they would roughly agree on the following description of the practice in question. A few minutes before dinner, the fellows of the College gather in the Senior Common Room and wear their gowns (long, black, cloak-like garments). Dinner is then announced by the sound of a trumpet. Fellows enter the dining hall and gather around the 'High Table' - a long table situated at the end of the dining hall,

\footnotetext{
${ }^{19}$ Dworkin, Law's Empire, p. 52.

${ }^{20}$ Dworkin, Law's Empire, pp. 65-68.

${ }^{21}$ Dworkin, Law's Empire, p. 67.

${ }^{22}$ Dworkin, Law's Empire, p. 67. See also Nigel Simmonds, Central Issues in Jurisprudence (London: Sweet \& Maxwell, 2002), p. 195.

${ }^{23}$ Dworkin, Law's Empire, p. 66.

${ }^{24}$ In Law's Empire, pp. 46-9, Dworkin uses the practice of 'courtesy' as an example.
} 
placed on a slightly higher level than students' tables. A member of the waiting staff strikes a gavel twice. In a court-like fashion, all students immediately stand up, and one of them thanks the Lord in Latin for the food they are about to receive. After saying 'grace', everyone sits down and the meal begins. Fellows are served three or four elaborate courses, and have to observe a few further rituals and conventions during the meal itself. The end of the meal is once again marked by the sound of the gavel. Everyone stands up, and the most senior diner says a brief word to thank to the Lord (in Latin as always), after which the fellows leave the dining hall.

While all interpreters agree on this description of the practice, they disagree about whether the practice, in its current form, appropriately expresses its underlying values. Consider, for instance, the following three interpreters: I1, I2, and I3.

I1 believes that, since the point of the practice is to affirm the value of academic hierarchy, the rules currently governing it are sub-optimal. In particular, he insists that, in order to express respect towards senior members of the College, students should not only stand up when the fellows enter and leave the dining hall, but also bow to them. I2, agrees with I1 about the point of the practice, and further suggests that, since the College is not a religious community, grace at the beginning and end of dinner should be abolished. Finally, I3 takes the radical view that High Table dinners should disappear. The College, he thinks, is an academic institution, and the values it fosters are hard work and academic excellence. In the old days, when academia was less competitive, High Table dinners were compatible with the promotion of these values. Today, they are just a distraction from academic pursuits and should be abolished.

I1, I2 and I3 all engage in constructive interpretation. They all look at a practice, ask about its point and purpose, and then propose a set of rules which would better express the point of the practice than the rules currently followed by its participants. 
In recent years, numerous political philosophers have also adopted the method of constructive interpretation to design moral principles in general, and principles of justice in particular. This 'interpretive turn' should come as no surprise. The practice-dependent approach underpinning constructive interpretation has many appealing features. Most importantly, although it rests on an analysis and interpretation of existing practices, it also contains valuable resources to criticise, reform - if not altogether abolish (recall I3) - them. In short, this methodology has the virtue of acknowledging the plurality of values and practices contained within our moral universe without a-critically endorsing the status quo.

As many have suggested, the later Rawls himself may plausibly be regarded as approaching the questions of domestic and international political morality from this interpretive, practice-dependent perspective. ${ }^{25}$ On this view, Rawls's justice as fairness is elaborated as an interpretation of society's main institutions and practices (pre-interpretive stage). The point of such practices is the production and distribution of social primary goods among free and equal persons (interpretive stage). The principles of domestic justice Rawls defends are meant to express the conditions under which society best realises this ideal. If society is to be a system of fair cooperation between free and equal citizens, its existing practices should be reformed in line with those principles (post-interpretive stage). ${ }^{26}$

By the same token, The Law of Peoples is thought to be arrived at by reflecting upon 'international law and practice' and the values they are meant to foster. ${ }^{27}$ These are the achievement of peace, stability, self-determination and fair cooperation between states. On

\footnotetext{
${ }^{25}$ James, 'Constructing Justice for Existing Practice’, pp. 298, 308ff.; See also Freeman 'The Law of Peoples, Social Cooperation, Human Rights, and Distributive Justice', p. 41; Sangiovanni, 'Global Justice, Reciprocity and the State', and 'Justice and the Priority of Politics to Morality', and Meckled-Garcia, 'On the Very Idea of Cosmopolitan Justice'. I do not mean to suggest that this is the correct interpretation of Rawls, but only that it is a plausible and increasingly popular one.

${ }^{26}$ For this interpretation of Rawls see James, 'Constructing Justice for Existing Practice’, p. 300.

${ }^{27}$ John Rawls, Political Liberalism, with a New Introduction and the 'Reply to Habermas' (New York: Columbia University Press, 1996), and The Law of Peoples.
} 
this reading of Rawls, the eight principles of the Law of Peoples express the conditions under which such values are best realised, and prompt us to reform international law and practice in line with them.

Since the point of international law and practice - i.e., the values these are meant to protect - clearly differs from that of domestic law and practice, social liberals who endorse this practice-dependent methodology conclude that principles of domestic justice are unsuitable for the international arena. Crucially, this conclusion is not premised on a denial of the moral primacy of persons. Instead, it is premised on a concern with preserving the distinctive values promoted within particular practices for the sake of individuals themselves. Human beings doubtlessly cherish their pluralistic moral world and the practices in which they participate. Respect for such pluralism therefore does not entail a lack of commitment to the moral primacy of the individual. Instead, it reflects a commitment to preserving those values that individuals hold dear.

In light of this, social liberals seem to have a powerful methodological response to the cosmopolitan charge of betrayal of normative individualism. To evaluate how powerful such a response really is, we first need to look at the practice-dependent approach in detail, and ask whether social liberals are right in claiming that it offers a good methodological standpoint for thinking about justice.

\section{PRACTICE-DEPENDENCE AND THE CONTENT OF JUSTICE}

Recall that, on a practice-dependent view, normative principles are to be regarded as interpretations of existing practices, and as such they must reasonably fit with a descriptive account of such practices. Although plausible in the case of a simple practice like High Table dining, this methodology has troublesome implications if it is employed to establish the content of higher-order moral ideals such as justice. In particular, following this 
methodology, principles of justice (i) remain problematically indeterminate ${ }^{28}$ and (ii) lack sufficient critical capacity.

To see this, let us consider the (uncontroversial) case of domestic justice, where social cooperation is the practice to be interpreted and citizens are the interpreters. Citizens presumably disagree about the values underpinning their social system, and about how these can be best instantiated in practice. The problem of indeterminacy arises because, so long as their different interpretations meet reasonable criteria of fit with their object, none of them can be excluded as 'invalid' or 'incorrect'. In such circumstances, society's rules cannot be established by reference to the 'true' account of justice (for no such account can be identified) but only by reference to the 'prevailing' one. ${ }^{29}$ On the practice-dependent approach, the content of justice is inevitably indeterminate, and the correct answer about what justice requires seems bound to rest on an arbitrary basis, namely on what a majority, or a powerful group within society, regard as the 'correct' interpretation of this value.

Notice that, from a liberal perspective, this aspect of practice-dependence is troublesome only when we are confronted with non-voluntary practices, such as societal membership. ${ }^{30}$ Things look different in the case of High Table dining. This is because, unlike in the societal case, participants who disagree with the prevailing view about the point of this practice and its governing rules can easily opt out of it. A person's ability to

\footnotetext{
${ }^{28}$ Note that, in the case of legal interpretation, Dworkin rejects the charge of indeterminacy and defends the so-called 'one right answer' thesis. See Law's Empire. For an overview of the debate on interpretation in legal reasoning see Julie Dickson, 'Interpretation and Coherence in Legal Reasoning', in Edward N. Zalta (ed.) The Stanford Encyclopedia of Philosophy (Fall 2008 Edition), http://plato.stanford.edu/archives/fall2008/entries/legal -reas-interpret/

${ }^{29}$ For criticisms of this interpretive methodology along similar lines, and particularly with reference to its use by Michael Walzer, see Joshua Cohen, 'Review of Spheres of Justice', Journal of Philosophy, 83 (8) (1986), 45768, and Normal Daniels, 'Review of Spheres of Justice', Philosophical Review, 94 (1) (1985), 42-8.

30 On the relevance of non-voluntary practices to judgements of justice see John Rawls, Justice as Reciprocity', 1993, in Samuel Freeman (ed.) John Rawls: Collected Papers, (Cambridge, MA: Harvard University Press, 1999), p. 190. See also 'Justice as Fairness', Philosophical Review , 67 (2) (1958), p. 179.
} 
lead a decent human life does not depend on her being a member of an Oxbridge College, or on her regularly attending College dinners.

A liberal can be a pluralist about different voluntary activities. People's conceptions of what counts as a life worth living vary, and this leads to the creation of different practices, governed by different rules. This form of pluralism is fully in line with the liberal commitment to the value of the individual, so long as those who engage in these voluntary practices can be assumed to accept the rules which govern them. By contrast, since life outside society is not an option, we cannot assume that membership in society indicates acceptance of its governing rules. When disagreement about these rules arises, liberals cannot simply content themselves with letting the strongest determine what justice requires. Yet, the practice-dependent approach seems to have no resources to avoid this outcome.

In addition to indeterminacy, there is a second, deeper problem with this approach, one that emerges even assuming away disagreement about what rules should govern society. On the practice-dependent view, the nature of the practice to be interpreted places significant constraints on the conception of justice which will result from the interpretive exercise. If principles of justice consist in an interpretation of existing practices, then they must fit with them.

For instance, any plausible interpretation of the point of a hierarchical society will result in a hierarchical conception of justice, according to which people's rights and opportunities vary depending on their social status. There is indeed no way in which interpreting the practices of, say, a caste society will lead to defend a liberal egalitarian account of justice. That account of justice simply would not fit its object of interpretation. In sum, on the practice-dependent view, principles of justice cannot be too detached from the status quoi.e., they are constrained by the particular practice of which they are an interpretation. If social practices happen to violate the liberal principle of the moral equality of persons, the 
practice-dependent view (in its original formulation) gives liberals no resources to criticise them as unjust because they violate that principle.

Surprisingly, this conclusion is problematic even from within a practice-dependent approach to justice. This point is nicely brought out by Ronald Dworkin himself, who explicitly rejects his own interpretive methodology when it comes to the design of higherorder moral concepts such as justice. Quite paradoxically, Dworkin notes, by leaving justice to existing shared understandings, we would fail to be true to 'the single most important social practice we have: the practice of worrying about what justice really is'. It is indeed 'part of our common political life, if anything is, that justice is our critic, not our mirror.' ${ }^{31}$ Consequently, an account of justice that is hostage to existing political practices seems to have to be rejected on practice-dependent grounds, insofar as it violates our shared understandings of the nature and function of justice.

Do the arguments presented in this section show that a practice-dependent approach to justice has to be abandoned altogether? Not necessarily.

\section{CONVENTIONALISM VS. INSTITUTIONALISM}

At this point, advocates of a practice-dependent methodology might object that my critique is successful only against one version of practice-dependence. Following Andrea Sangiovanni, ${ }^{32}$ they might say that while 'cultural conventionalism' à la Michael Walzer is indeed implausible in the way just described, 'institutionalism' à la Rawls is not. There is one main difference between these two forms of practice dependence.

While conventionalists construe principles of justice as a direct articulation of participants' beliefs and self-understandings, says Sangiovanni, institutionalists do not

\footnotetext{
${ }^{31}$ Dworkin makes these remarks in the context of a famous dispute with Michael Walzer. Ronald Dworkin, 'What Justice Isn't', in R. Dworkin, A Matter of Principle (Oxford: Clarendon 1989), pp. 214-220, p. 219.

${ }^{32}$ Sangiovanni, 'Justice and the Priority of Politics to Morality', p. 146.
} 
attribute much justificatory weight to participants' beliefs. ${ }^{33}$ 'For the institutionalist, relationships [and beliefs] established by shared institutions condition rather than determine appropriate criteria of justice, ${ }^{34}$ This is because, unlike conventionalists, institutionalists explicitly endorse the 'higher-level moral principle that all human beings should be treated with equal, ultimate, and general moral concern. ${ }^{35}$ This principle is clearly practiceindependent: its form, content, and scope are not derived from an interpretive analysis of existing practices. They are discovered a priori. To this extent, institutionalists agree with practice-independent theorists.

Unlike them, however, they believe that, so formulated, the principle is devoid of any content. While for practice-independent theorists the principle of the moral equality of persons directly tells us what we owe to each other - i.e., universal obligations of distributive justice - for institutionalists, what we owe to each other given our fundamental moral equality depends on the specific types of institutions in which we participate. What the principle of equal respect requires is that such institutions be justifiable in the eyes of all participants.

33 Another, less important (and less clear), difference pointed out by Sangiovanni, is that while for conventionalists moral principles vary depending on the particular societal culture underpinning the practices they are meant to govern (on the assumption that this is homogenous enough to deliver a unique interpretive outcome), for institutionalists the content and scope of principles of justice is a function of the particular institutional form they are meant to regulate. In other words, instead of resting on culturally-specific instantiations of the practice of society (e.g., hierarchical societies, democratic societies, theocratic societies etc.) institutionalist principles are a function of the particular type of institution to which they apply (e.g., societies, families, international organisations). This allows institutionalists to place institutions which are not underpinned by a particular societal culture - e.g., the WTO - under justice-based assessment. However, institutionalists are also ready to acknowledge that 'the form and structure of institutions often depend on underlying cultural beliefs and practices'. Sangiovanni, 'Justice and the Priority of Politics to Morality', p. 146. Since, as Sangiovanni himself acknowledges, this second difference between conventionalism and institutionalism is far from sharp, and given that nothing hinges on it for the purposes of my argument, I shall not discuss it further in the paper.

${ }^{34}$ Sangiovanni, 'Justice and the Priority of Politics to Morality', p. 147, emphasis original.

${ }^{35}$ Sangiovanni, 'Justice and the Priority of Politics to Morality', p. 147. 
In light of its distinctive structure, institutionalism can avoid the most morally repugnant implications of conventionalism. While conventionalists seem to have no resources to criticise the practices of a racially discriminating, or deeply hierarchical, society - because presumably there is no plausible interpretation of that practice compatible with the moral equality of persons - institutionalists can easily do so, since there is no plausible principle according to which the terms governing such a society could be regarded as justifiable in the eyes of all members. Members might actually endorse such practices, but this would only show that they are the victims of adaptive preferences or false consciousness. ${ }^{36}$ In other words, institutionalists can honour liberal normative individualism and engage in moral criticism, by ruling out as illegitimate those practices which cannot plausibly be justified to all participants.

It is true that institutionalism would still be faced with the issue of how to determine the correct understanding of justice in the face of disagreement. But this need not constitute such a devastating problem for institutionalism. Institutionalists can simply respond, in a Rawlsian fashion, that there may exist a plurality of 'reasonable' accounts of justice: reasonable because compatible with equal respect understood in terms of mutual justifiability. To the extent that the practices of a society fall within the reasonable range, the specific form its institutions should take has to be determined through the democratic political process of the society in question. ${ }^{37}$ For instance, we might think that liberaldemocratic civil and political rights, and a minimum level of welfare are necessary conditions for a society to count as 'reasonably just'. Once such conditions are met, however, each society can promote its favoured interpretation of justice (i.e., the interpretation favoured by its majority) without it being a matter of serious moral concern.

\footnotetext{
${ }^{36}$ Sangiovanni, 'Justice and the Priority of Politics to Morality', p. 163.

${ }^{37}$ Rawls, The Law of Peoples (esp. 'The Idea of Public Reason Revisited') and Gerald F. Gaus, 'The Demands of Impartiality and the Evolution of Morality', in Brian Feltham and John Cottingham (eds) Partiality and Impartiality (Oxford: Oxford University Press, forthcoming).
} 
The impossibility of identifying a uniquely correct account of justice is a consequence of the limits of human reason and, as such, there is little that political philosophers can do about it.

Although some might certainly want to object further to this Rawls-inspired response, it is uncontroversial that institutionalism significantly improves on the conventionalist solution. The problems generated by the absence of a morally valid criterion on the basis of which to identify a uniquely correct conception of justice are in large part compensated for by the presence of a morally valid criterion placing liberal constraints on the content of any reasonable such conception.

As I said, this distances institutionalism from conventionalism, but is it enough to rescue the institutionalist defence of social liberalism from the charge of betrayal of the fundamental liberal commitment to the moral equality of persons? Not quite.

\section{PRACTICE-DEPENDENCE AND THE SCOPE OF JUSTICE}

Recall that the main objection to the practice-dependent stance in the context of the debate on global justice does not challenge the content of social liberal principles of distributive justice (they are liberal egalitarian), but their scope. The fact that, unlike conventionalism, institutionalism does not run the risk of endorsing morally perverse social practices does not suffice to show that it does not arbitrarily exclude some agents from the scope of distributive justice.

To see whether institutionalism has the resources to avoid this difficulty, we need to look at the institutionalist - as opposed to conventionalist - justification of principles of distributive justice. In this respect, Sangiovanni considers the later Rawls's defence of justice as fairness as a very good example of institutionalist justification. ${ }^{38}$ For Rawls, the content and scope of principles of distributive justice are to be defined by appeal to 'the function

\footnotetext{
${ }^{38}$ It is worth noting that Sangiovanni's own version of institutionalism is slightly different from Rawls's (see 'Justice and the Priority of Politics to Morality', p. 150 n. 30) and his take on international justice more nuanced than Rawls's (see 'Global Justice, Reciprocity, and the State').
} 
justice is intended to play within the social and political institutions of a constitutional democracy'.39

Accordingly, the content of Rawls's principles is determined by analysing the particular goods produced within a domestic society understood as a system of fair cooperation among free and equal citizens. The result is a set of principles requiring a roughly equal distribution of primary social goods such as rights, opportunities, resources, income and wealth, among citizens. ${ }^{40}$ But what about the scope of distributive justice? How does the institutionalist establish the context to which principles of distributive justice should apply?

The assumption that the domestic arena constitutes the proper locus of distributive justice is based on a deeply entrenched conviction that distributive justice should apply to political communities. The fact that institutionalism endorses this starting point should come as no surprise, and is no reason for criticism. The question is whether, from within an institutionalist perspective, we can meaningfully ask: Should principles of distributive justice be extended to the world at large? The answer seems to be no.

Like cultural conventionalism, institutionalism fails to offer an account of the function of distributive justice allowing us to 'uncouple' it from a particular understanding of an existing practice. The function of distributive justice, on the institutionalist view, is to determine how entitlements to social goods should be distributed between members of a statelike political community. In this respect, recall Sangiovanni's claim that principles of distributive justice are designed by appeal to 'the function justice is intended to play within the social and political institutions of a constitutional democracy'. ${ }^{41}$ If this is the function distributive justice is meant to play, then it is no surprise that it cannot apply to the international order.

\footnotetext{
${ }^{39}$ Sangiovanni, 'Justice and the Priority of Politics to Morality', p. 151.

${ }^{40}$ Sangiovanni, 'Global Justice, Reciprocity, and the State'.

${ }^{41}$ Sangiovanni, 'Justice and the Priority of Politics to Morality', p. 151.
} 
But why does the institutionalist define justice in this way? If distributive justice is fundamentally about respecting other people's spheres of agency, why should its application be confined to particular kinds of institutions - i.e., those we find within domestic political communities?

There is a simple explanation for this. The domestic context is often perceived as the only, or most important, realm within which persons can affect each other's life prospects through participation in common institutions. So long as people living within different communities have no on-going impact on each other's opportunities to act, their relations need not be regulated by principles of distributive justice. By contrast, individuals living within the same community routinely affect one another's lives and opportunities, and the way to ensure that each is in a position to pursue her ends and goals without infringing others' rights to do the same is to implement principles of distributive justice. This is indeed the explicit aim of Rawls's theory of domestic justice. Justice as fairness sets out the principles according to which citizens of the same state can be in a position to form, revise and pursue their conceptions of the good, without preventing others from doing the same.

The problem with institutionalism is that it turns a contingent (and perhaps superseded) empirical fact - i.e., the fact that respecting other people's spheres of agency requires distributive justice only within domestic political communities - into a conceptual truth about justice - the idea that justice is about the distribution of certain kinds of goods between citizens.

However, including only fellow-citizens in the scope of justification might fail to show equal respect to those human beings whose agency we affect, and rely on, in our day-to-day activities, but who do not qualify as citizens. By tying the idea of distributive justice to the institution of citizenship, institutionalists do not have the theoretical resources properly to 
address the question of whether principles of distributive justice should extend beyond the domestic context. ${ }^{42}$

At this point institutionalists might protest that I am mischaracterising their views. In particular, they might suggest that my entire discussion has begged the question against the practice-dependent approach they favour. For the view they defend is precisely that justice has no unique function. Instead, its role differs across different practices. As Sangiovanni says, '[b]ecause the role of justice in international affairs ... is not to mediate relations among citizens of a constitutional democracy, the first principles appropriate for the international order will have a correspondingly different content, scope, and justification'.43 This is different from claiming that no form of justice applies at the global level. Instead, it means that different conceptions of justice apply to different institutional contexts (including international institutions such as the WTO and the EU) in light of their point and purpose. Although Rawls himself may not have fully appreciated these implications of institutionalism (given his rather thin theory of international justice), other institutionalist approaches, like Sangiovanni's, are more nuanced in this way.

I find the idea that justice may entail different duties within different domains highly plausible, but the institutionalist articulation of it leaves me unpersuaded. This is because, by suggesting that the very function of justice changes across contexts, institutionalists seem to end up robbing justice of its normative distinctiveness. They tell us that different conceptions of justice apply to different institutions in light of our different interpretive understandings of them, but do not tell us how such conceptions represent interpretations or instantiations of the same concept. On this institutionalist view, principles of assistance

\footnotetext{
42 Aaron James, 'Constructing Justice for Existing Practice', pp. 308-16, considers the objection that Rawls's methodology unfairly excludes non-participants from the scope of justice, and replies that interpretive reasoning need not exhaust (Rawls's) reasoning about justice: other aspects of it may allow us to take 'outsiders' into consideration. This answer, however, seems to confirm, rather than deny, that interpretive reasoning is indeed susceptible to the charge of unfair exclusion.

${ }^{43}$ Sangiovanni, 'Justice and the Priority of Politics to Morality', p. 152.
} 
requiring us to help other peoples in need, human rights norms placing limits on state sovereignty, and domestic principles requiring a roughly equal distribution of social goods all count as principles of justice. However, the reason why this is so remains unclear. ${ }^{44}$

Moreover, while this institutionalist response might point to an interesting methodological stance, it would probably not entirely satisfy the cosmopolitan critic. In her view, whether certain principles count as principles of justice or not depends on their structure and function, not on the label attached to them.

At this point institutionalists might attempt a second line of reply, and suggest that, contrary to what I argue, they do defend a general, practice-independent account of the function of justice. After all, don't they claim that justice is always about equal respect understood in terms of inter-subjective justifiability? In turn, the requirement of intersubjective justifiability applies to different practices, thus delivering a set of practicespecific substantive principles of justice.

This is a valid consideration, but one that, paradoxically, takes institutionalists too far. If the construal of justice as a matter of distribution between citizens is too narrow, its construal in terms of inter-subjective justifiability is too broad. The idea of inter-subjective justifiability is too vague to ground a plausible account of principles of justice (as opposed to other kinds of moral principles). For instance, obligations of beneficence clearly meet an inter-subjective-justifiability test. The principle 'you ought to help those in need so long as this is not too costly to yourself is inter-subjectively justifiable, but is paradigmatically not a principle of justice. Instead, it is a principle of beneficence or assistance. Inter-subjective justifiability appears to be a constraint we should place on moral principles generally, and not solely on principles of distributive justice.

\footnotetext{
${ }^{44}$ This is not to say that a further developed institutionalist view may not be able to offer a general concept of justice.
} 
To conclude, although (as we have seen in section V) institutionalism considerably improves on cultural conventionalism insofar as it appeals to a morally valid criterion on the basis of which to assess the content of principles of distributive justice, it still fails to offer an equally valid criterion to determine their scope. Indeed, the institutionalist account of justice is either too narrow (it defines justice as a matter of distribution across citizens only and thereby confines it to the domestic domain) or too broad (thus depriving justice of its distinctive normative features). Can some other variant of a practice-dependent approach do better? I believe it can.

\section{FUNCTIONALISM}

It seems to me that there exists another version of practice-dependence which does not succumb to the cosmopolitan charge, although it is unlikely to yield social liberal conclusions. This is the version of practice-dependence on which several cosmopolitan theorists rely when they argue that principles of distributive justice should apply worldwide in virtue of the existence of appropriate practices at the global level.

Even though different cosmopolitan theorists characterise such practices in different ways, instead of appealing to our interpretive understandings of existing institutions, they all focus on social rules and patterns of interaction which de facto shape people's life prospects and opportunities to act, and from which individuals cannot escape. ${ }^{45}$ The idea is that, if justice is about respecting persons' equal right to lead lives they deem worth living, the way

\footnotetext{
${ }^{45}$ Recall my earlier remarks about non-voluntariness. These kinds of rules are often referred to using the Rawlsian term 'basic structure'. I agree with Miriam Ronzoni, however, that sufficiently intense patterns of interaction, with foreseeable effects on people's opportunities and well-being, can trigger concerns of distributive justice even if they are not yet regulated by basic structural rules. See Miriam Ronzoni, 'The Global Order: A Case of Background Injustice? A Practice-Dependent Account', Philosophy and Public Affairs, 37 (3) (2009), 229-56. For an analytical account of different ways in which the idea of a basic structure might be characterised in relation to questions of global justice see Arash Abizadeh, 'Cooperation, Pervasive Impact, and Coercion: On the Scope (not Site) of Distributive Justice', Philosophy \& Public Affairs, 35 (4) (2007), 318-58.
} 
in which people mutually shape and constrain their opportunities to act by interacting with one another should be consistent with each maintaining this equal right.

Here, the membership criterion - hence the scope of justification - is not modelled on the basis of our interpretive understandings of existing institutions, instead it rests on a practice-independent account of the function of justice. This is why I call this family of approaches functionalism about justice. Functionalists do not define distributive justice in connection with the institution of citizenship, of the family, of international law and so forth. Instead, they understand distributive justice solely in terms of its practice-independent function, and then ask to what relations and practices it should apply: namely those which shape persons' life-prospects and opportunities, and from which individuals cannot escape.

Versions of what I call functionalism have recently been defended by several political philosophers, though typically in support of cosmopolitan conclusions. For instance, Joshua Cohen and Charles Sabel have defended the idea that the global order calls for more than duties of humanitarian assistance because 'the rules made in [international] settings are consequential for the conduct and welfare of individuals, firms, and states, in part because they provide standards for coordinated action and in part (though not only) because national rule-making itself proceeds subject to rules, standards and principles established beyond the national level'. ${ }^{46}$

Similarly, following Onora O’Neill, Iris Marion Young discusses how we implicitly rely on the existence of world-wide practices in a myriad of ordinary activities. ${ }^{47}$ Were it not for the agency of distant workers who produce the goods that we buy, we would be unable to do our daily shopping. Even though we may not perceive ourselves as shaping their

\footnotetext{
${ }^{46}$ Cohen and Sabel, 'Extra Rempublicam Nulla Justitia', p. 165.

${ }^{47}$ Iris Marion Young, 'Responsibility and Global Labor Justice', Journal of Political Philosophy, 12 (4) (2004), 365-88; Cf. Onora O’Neill, Faces of Hunger (London: Allen and Unwin, 1985), and Towards Justice and Virtue: A Constructive Account of Practical Reasoning (Cambridge: Cambridge University Press, 1996).
} 
opportunities to act, by participating in the world economy and market system, in fact we do, and thereby have duties of justice towards them.

In a similar vein, Thomas Pogge forcefully argues that wealthy westerners have duties of distributive justice towards the world's poor because they support global institutional rules which, foreseeably and avoidably, contribute to their plight. ${ }^{48}$

In all of these examples, the conclusion that distributive justice should apply beyond the state level is reached by pointing to the existence of rules or patterns of interaction which affect and constrain persons' ability to lead lives they consider worth living, and from which they cannot subtract themselves. No matter whether this conclusion is correct something on which I shall say nothing in this paper - the practice-based methodology through which this conclusion is arrived at remains unaffected by the charge of arbitrary exclusion cosmopolitans level against social liberals. This is because the functionalist version of practice-dependence offers a general account of the function of distributive justice - that of respecting persons' equal right to pursue their ends and goals - and selects the practices or types of interaction to which distributive justice should apply, in light of its function.

By contrast, the earlier versions of practice-dependence employed by social liberals construe distributive justice as an expression of the value of citizenship, and consequently limit its applicability to the practice of living together within the same state. On this view, what we already think about the scope of distributive justice - i.e., it applies among fellow-

\footnotetext{
${ }^{48}$ Thomas W. Pogge, World Poverty and Human Rights: Cosmopolitan Responsibilities and Reforms (Cambridge: Polity Press, 2002). In 'Global Justice, Reciprocity, and the State' Sangiovanni says that his view is meant to be compatible with Pogge's thesis that 'our joint imposition of the current global order makes us negatively responsible for massive human rights violations' (p. 4, n. 5). This, says Sangiovanni, is because Pogge does not advocate global equality, but only human rights fulfilment. Even though, like Sangiovanni, in his later work Pogge is not a global egalitarian, from a structural and methodological viewpoint his views seem to me considerably different from Sangiovanni's. In particular, Pogge's claims about the global order, and the principles of justice which should apply to it are not defended on the basis of the interpretive approach Sangiovanni advocates, but on the basis of observations regarding empirical facts about international/global politics.
} 
citizens - defines what this scope ought to be. This is why practice-dependent social liberals cannot treat the question 'Do we have duties of global distributive justice?' as a philosophically interesting one. On their approach, the answer to the question, 'Is practice $\mathrm{X}$ an appropriate subject of distributive justice?', depends on whether we already consider those affected by $\mathrm{X}$ as co-participants in some relevant sense - particularly whether we think of them as fellow-citizens - and ourselves as owing them justice, irrespective of the actual impact that our activities have on them. Whether we owe these people justice depends on whether we think we do.

What is troublesome about this approach is that it assumes an interpretive understanding of a specific institution as the subject of distributive justice, thus rendering the question of the scope of justice redundant. ${ }^{49}$ Even though advocates of this approach are keen to emphasise that the ethical significance they attribute to existing practices need not entail a betrayal of normative individualism, such a worry cannot be dispensed with quite so easily. In cases of discrepancy between our interpretive understandings and our actual impact, social liberal principles designed via the interpretive approach are bound to overlook the justice-based interests of some persons, in this way succumbing to the cosmopolitan charge.

Functionalism does not fall into this trap. Having said that, it is worth noting that a functionalist, practice-dependent approach to distributive justice need not deliver the same conclusions as a practice-independent one. Practice independent theorists typically argue that the same principles of distributive justice which apply to the domestic context should

\footnotetext{
49 This claim differs from Arash Abizadeh's observation that fair cooperation cannot be an existence condition of justice because otherwise justice would (paradoxically) only apply to relations that are already fair. See Abizadeh, 'Cooperation, Pervasive Impact, and Coercion', pp. 330-1. Practice-dependent social liberals do in fact acknowledge that justice applies to practices in which fairness has not yet been achieved (e.g., to unjust societies).
} 
also apply to the world at large. ${ }^{50}$ In other words, they typically argue for extending domestic conceptions of distributive justice beyond state borders, on the grounds that this is what equal respect requires.

Whether functionalists come to the same conclusion - and thereby support full-blown cosmopolitanism - depends on their beliefs about empirical facts. That is, it depends on whether they think that the ways in which we place constraints on one another's agency at the domestic level are the same as the ways in which we do so internationally. It is perfectly conceivable that different types of practices or relations will place different kinds of constraints on agency, constraints that should be justified by appeal to principles of justice whose content varies across them. However, their function will remain the same: that of respecting persons' equal right to pursue their plans of life.

A functionalist may, for instance, insist that Rawls's justice as fairness is appropriate in the domestic context: its principles are those which allow states to realise persons' equal right to pursue their ends and goals. However, she might add, these principles are not appropriate in the global arena. Globally, the functionalist might continue, we need principles placing constraints on power-inequalities across states, so as to make sure that each of them is in a position to secure their citizens' right to lead lives worth living. These principles, in turn, might call for some significant redistribution, institution-building, and reform at the global level. However, they need not coincide with domestic ones. ${ }^{51}$

In other words, functionalist theorists can (but need not) claim both that the concept of distributive justice extends to the world at large - i.e., that our international morality demands more than assistance - and that the most appropriate 'international' conception of

\footnotetext{
50 See, e.g., Caney, Justice beyond Borders, Tan, Justice without Borders, and Beitz, 'Cosmopolitan Ideals and National Sentiment'.

${ }^{51}$ Cf. the powerful argument in Ronzoni 'The Global Order: A Case of Background Injustice?'.
} 
such a concept differs from the one we defend within domestic political communities. ${ }^{52}$ Justice always has the same function - protecting persons' equal right to lead lives worth living - but the principles through which this function is globally achieved may vary across different contexts.

This suggests that functionalism can reach conclusions that are similar in structure to those reached by institutionalism (different principles apply to different contexts), but not necessarily in content. This is because, under functionalism, the varying conceptions of justice defended across different contexts all fulfil the same function, namely ensuring respect for persons' equal right to lead lives worth living. For institutionalists, on the other hand, these principles all fulfil different functions, in light of the different interpretive understandings of the practices to which they apply.

Before concluding, let me point out that, in this section, I have not defended functionalism against practice-independent approaches to justice, but only tried to show that a practice-dependent approach can escape the cosmopolitan charge I have been examining here, albeit with the likely side-effect of supporting conclusions much closer to cosmopolitan than social liberal ones. Whether functionalist approaches are successful allthings-considered, however, is a question for future investigations.

\section{CONCLUSION}

In this paper, I have assessed the claim that social liberals' confinement of principles of distributive justice to the domestic arena betrays the fundamental liberal commitment to the moral equality of persons and arbitrarily discriminates in favour of compatriots. To make my case as robust as possible, I have considered what I take to be the most general formulation of such a charge and the strongest social liberal response to date. Such a response focuses on the particular practice-dependent methodology social liberals adopt to

\footnotetext{
52 See, e.g., Cohen and Sabel, 'Extra Rempublicam Nulla Justitia', and Beitz's account of weak cosmopolitanism in Political Theory and International Relations, pp. 198-99.
} 
design moral principles. Following this methodology, social liberals are led to conclude that there are morally relevant disanalogies between domestic and international settings which warrant the application of distributive justice to the former but not to the latter.

Without taking an explicit stand on the plausibility of this conclusion, I have argued that the methodology through which social liberals reach it is problematic. In particular, I have looked at two versions of practice-dependence, cultural conventionalism and institutionalism, and argued that they both fail to respond to the cosmopolitan charge. Cultural conventionalism disregards this moral equality at the level of the content of the principles it generates. Institutionalism, on the other hand, fails to offer a plausible account of the considerations which determine the scope of principles of distributive justice.

In addition, I have argued that this does not mean that any approach tying the applicability of principles of distributive justice to existing practices is doomed to be vulnerable to this cosmopolitan charge. Indeed, there is a third form of practicedependence - which I call 'functionalism' - that can avoid the criticisms advanced against cultural conventionalism and institutionalism. Whether functionalism could support social liberal conclusions is a question I have not explored in detail in this paper, and whose answer depends on empirical facts about contemporary global politics. However, I have offered some evidence suggesting that this is unlikely to be the case.

Finally, let me point out that my argument was not meant to be a rebuttal of the substantive conclusions of social liberalism, or an endorsement of those of cosmopolitanism. In this paper I did not take a view on whether distributive justice does actually apply beyond borders, although admittedly my argument speaks in favour of that general claim. My only aim has been to show that, so long as the social liberal thesis that it does not is defended by appeal to a particular kind of methodology - be it cultural conventionalism or institutionalism - it will fail to respond to a powerful cosmopolitan charge. 